\title{
SKETCH-UP
}

\section{Intra-plate volcanism}

Nat. Geosci. http://dx.doi.org/10.1038/s41561-017-0035-y (2017)

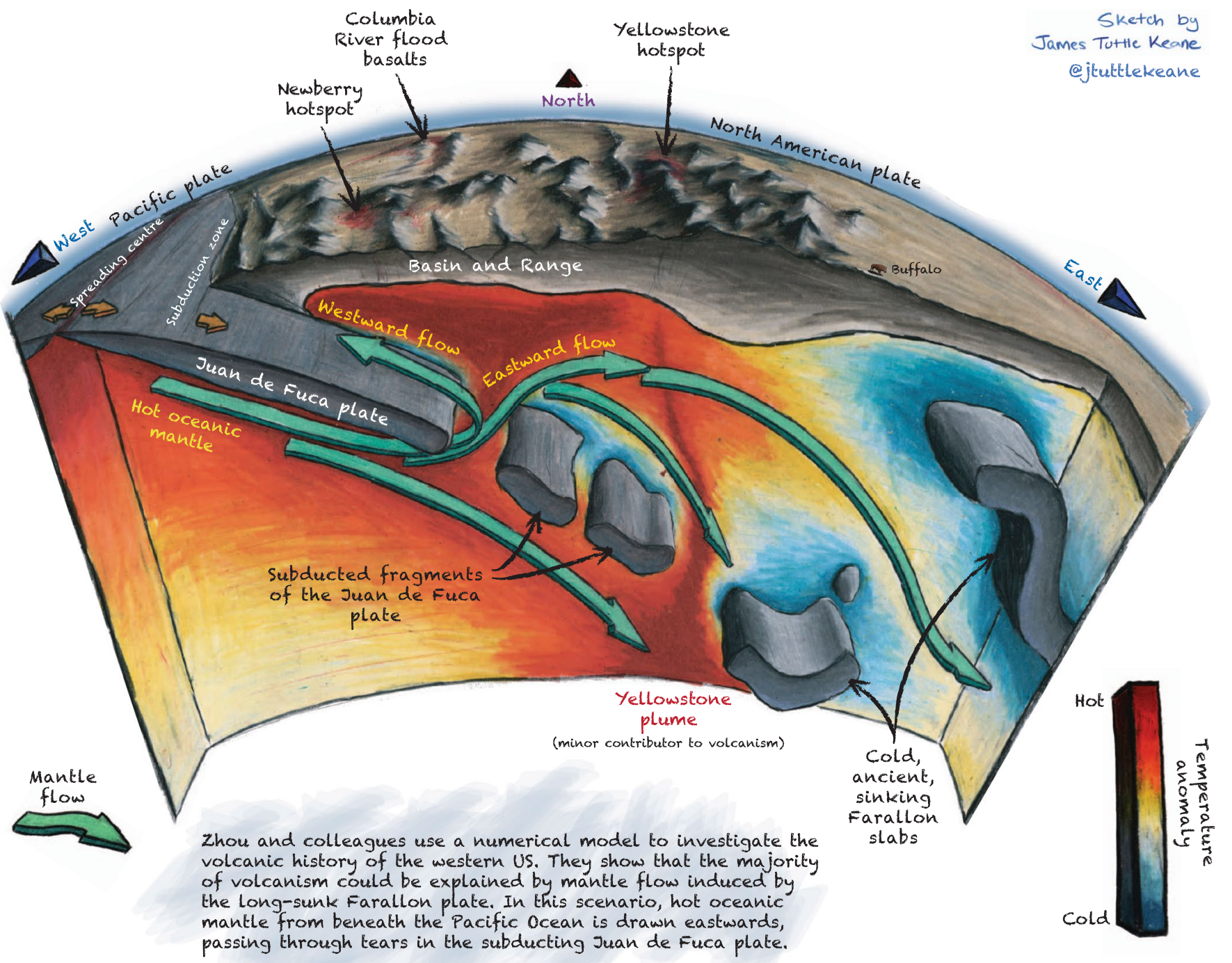

Published online: 18 December 2017

https://doi.org/10.1038/s41561-017-0048-6 